\title{
Traditional Rainwater Harvesting and Water Conservation Practices of Kerala State, South India
}

\author{
V S Joji* \\ Central Ground Water Board, Ministry of Water Resources, River Development \& Ganga Rejuvenation, \\ Thiruvananthapuram, Kerala, India. \\ *Corresponding author: V S Joji, Central Ground Water Board, Ministry of Water Resources, River Devel- \\ opment \& Ganga Rejuvenation, Thiruvananthapuram, Kerala, India; E-mail: jojivsdh@yahoo.com
}

Received Date: 10 September, 2018; Accepted Date: 02 November, 2018; Published Date: 14 November, 2018

\begin{abstract}
Kerala state ('God's Own Country') experiences copious rainfall with an average annual rainfall of $3000 \mathrm{~mm}$ received during northeast \& southwest monsoon seasons spread over 106 rainy days. Due to physiographic set up of Kerala State and very less recharge, the state is experiencing severe water scarcity during lean period (March to May). The problems like decline in the depth to the water level, drying up of dug-wells, water salinity along the coastal areas due to tidal effect are the common other problems in Kerala State. Fortunately, saline water has not been reported in any of the areas in Kerala State due to steep slope towards the Laccadive sea in the western part of this tiny state. In order to circumvent the various problems faced by the people in water sector, people of Kerala State has increasingly adopted various types of artificial recharge method, traditional rainwater harvesting and water conservation practices for the sustainability of water resources. The present concept paper also briefly discusses tanks and ponds especially temple ponds, sacred groves very rare in different parts of the world, surangams, role of coconut and arecanut basis in water conservation and simplest traditional rainwater harvesting structures.
\end{abstract}

\section{Keywords}

Artificial recharge; Dug-wells, Pond; Sacred groves, Surangam; Water level

\section{Introduction}

Water is the elixir of life. Water is one of the essential ingredients to sustain life. The water exists as surface water, groundwater, and as water vapour on earth. But only $2.5 \%$ of this water is fresh water and suitable for human consumption. [1]. Almost all the major demands of water are met from this fresh water resource. Quite recently the population explosion coupled with changing life-styles has created a crisis-like situation in the water sector. Hence rainwater harvesting, and artificial recharge practices have gained prominence in this sector [2].

It has become the need of the hour. The artificial recharge is the process of recharging water into the ground water system by artificial means for the sustainability of ground water and without sacrificing the needs of future generation. The rainwater so collected can be stored for future use in storage tanks or diverted to augment the groundwater system. In this study, hydrogeological information of the Kerala State (South India) is mapped and related to the Traditional Rainwater Harvesting and Water Conservation Practices.

\section{Study area}

Kerala, popularly known as the 'God's Own Country', has a coastal length of $600 \mathrm{~km}$ on the Malabar coast of India. The state of Kerala State is well known for its greenery, backwater systems and inland navigation, innumerable number of rivers, water falls, reservoirs, mountainous terrain with tea, rubber, coffee plantations, and high diversity in flora and fauna. The state of Kerala State is blessed with Eravikulam and Periyar national parks and other wild life sanctuaries including Wayanad and are the habitats of tigers, elephants, langurs, monkeys, deer and so on. The State has an aerial extent of 38,893 sq. $\mathrm{km}$ and has been divided into 14 districts, $152 \mathrm{commu}-$ nity blocks, 978 Gram panchayats, 5 Corporations and 60 Municipalities. The state has a total population of 33,387,677 persons [3]. There are 1084 females for every 1000 males. The population density is $911 / \mathrm{sq} . \mathrm{km}$. The various types of soil in Kerala State include lateritic soil, alluvium (coastal and riverine), brown hydromorphic soil, greyish onattukara soil and forest loam [4]. Kerala is a tiny strip of land, located in the southwestern tip of India between North latitudes $8^{\circ} 18^{\prime}$ and $12^{\circ} 48^{\prime}$ and East longitudes $74^{\circ} 52^{\prime}$ and $77^{\circ} 22^{\prime}$, occupying only 1.2 percent of India's land area (3,287,263 sq. $\mathrm{km}$ ), 3 percent of country's population inhabits the State. The location map of Kerala is compiled (Figure 1). 
Citation: Joji VS (2018) Traditional Rainwater Harvesting and Water Conservation Practices of Kerala, South India. J Aquat Res Mar Sci 2018: 84-90. DOI: https://doi.org/10.29199/2639-4618/ARMS.102022.

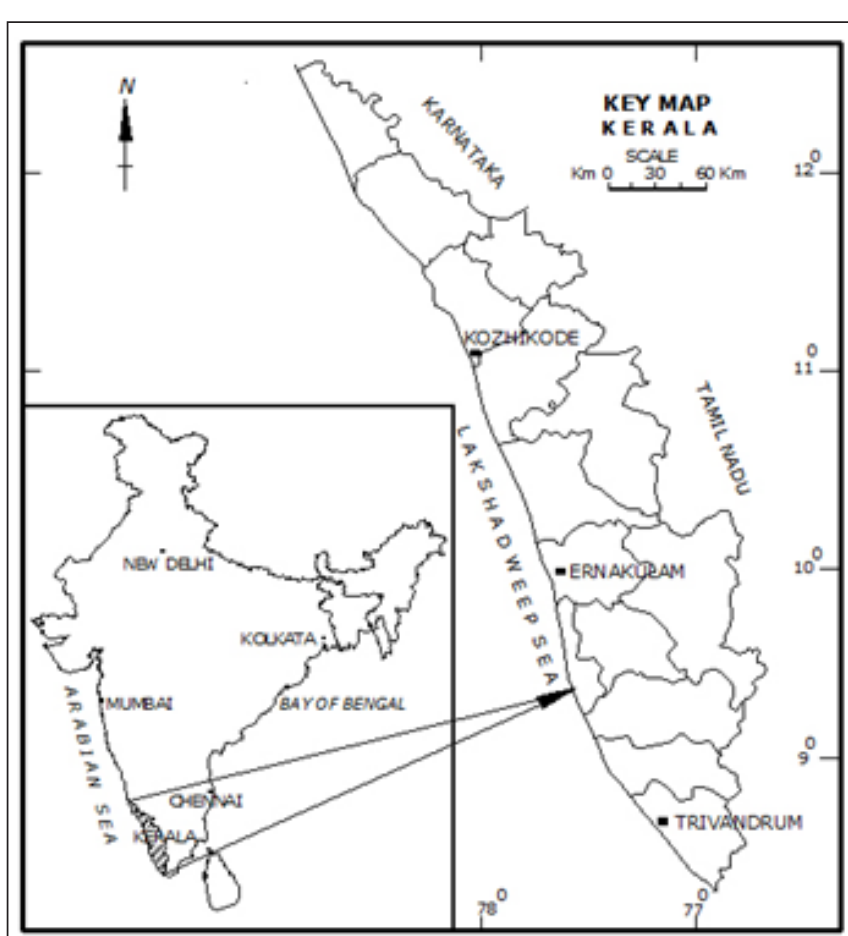

Figure 1: Location map of Kerala state, South India.

A diverse type of land use / land cover and cropping pattern are characteristic features of Kerala. Out of total geographical area of 3886287 hectares $28 \%$ of the area is under Forest. Agriculture is practiced in over $53 \%$ and area under non-agricultural use is 10 $\%$. Coconut, arecanut, Paddy, Jackfruit, cashew, rubber, pepper, tea, coffee, cardamom and other spices are the crop types cultivated in Kerala. Total cropped area is 2089029 hectares. The state has completed around 15 Major Irrigation Projects and there are many ongoing projects. There are about 430 completed lift irrigation projects spreading over the districts mostly Ernakulam, Malappuram, Palakkad, Pattanamthitta and Thrissur Districts. Mineral resources of the state consist of heavy mineral sands, silica sands, clay deposits (kaolin and bauxite), graphite, gemstones, Iron deposits, gold etc.

Kerala State has Wet Tropical Monsoon climate, offering a pleasant atmosphere throughout the year. Summer extends from the month of April to June. The maximum temperature ranges up to $33^{\circ} \mathrm{C}$ and minimum temperature remains within $20^{\circ} \mathrm{C}$. Kerala State receives copious rainfall with an average annual rainfall of $3000 \mathrm{~mm}$ each year. Rainfall is received during two monsoon seasons (northeast \& southwest) spread over 106 rainy days. Kerala State is drained by 44 rivers and among these 41 rivers are west- and others are east-flowing rivers. The estimated annual yield of 44 rivers of Kerala State is 70.323 million cubic meters (MCM). Kerala's western coastal belt is interrupted by a system of interconnected salty channels, estuaries, lakes and rivers known as the backwaters. Based on elevation Kerala is divided into three physiographic zones- low land (elevation less than 7.6 m. above mean sea level) occupied by Tertiaries and alluvium, mid land (between 7.6 and $76 \mathrm{~m}$. above mean sea level) occupied by exposure of Charnockites and Khondalites and are overlain by laterite and High land with an elevation of more than $76 \mathrm{~m}$. above mean sea level occupied by various Gneisses, Khondalites and Charnockites. The eastern part of the state is bounded by Western Ghats / Sahyadris and western part Laccadive Sea The geomorphic / physiographic map of Kerala State is compiled (Figure 2).

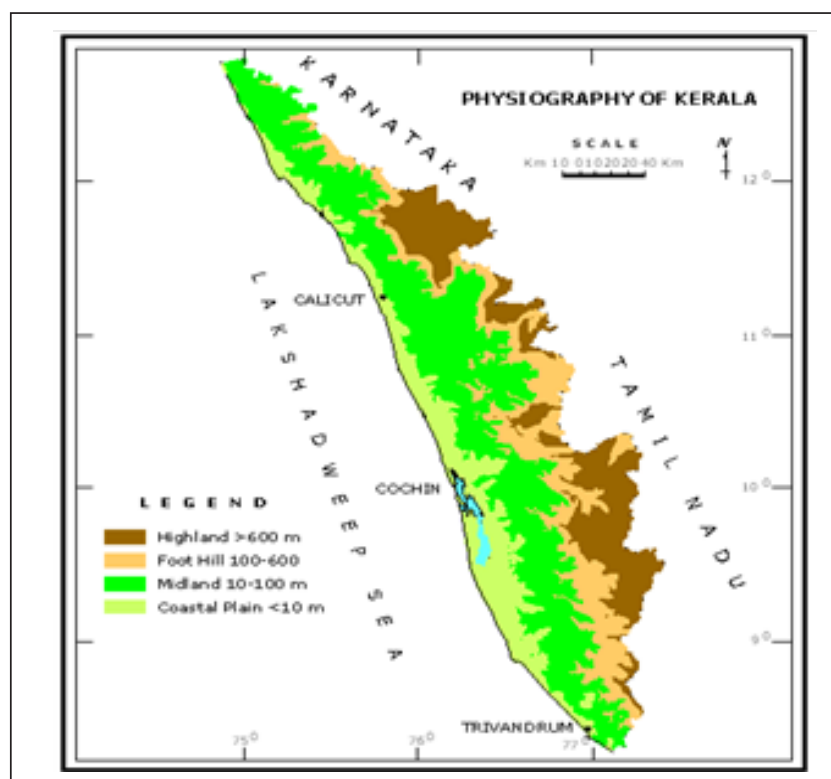

Figure 2: Geomorphologic map of Kerala.

\section{Materials and methods}

The degree sheets of 1:2,50,000 scale (SOI, 1968) have been used for the preparation of base map (figure 1) and various layers. Prior to analysis, the maps have been projected on [WGS 84] [EPSG: 4326], digitized, edited and given annotations by Map Info 6.5 techniques. The digitized maps were edited. During editing segment checking like intersection, self-overlap and deadend corrections were carried out. Projection and polygonization of units followed the editing. After polygonization annotations were given for different polygons and the maps were ready for analysis. The manipulation of various layers has been carried out by using Map Info 6.5 methods. The hydrogeological studies carried out in Kerala State have been incorporated in the present work.

\section{Results and discussion}

The various activities and aspects related to the Traditional Rainwater Harvesting and Water Conservation Practices of Kerala State, South India are briefly discussed.

\section{Hydrogeological Scenario}

The $88 \%$ of the State of Kerala State is underlain by Precambrian crystalline formations like charnockites, Khondalites, schists and gneisses and are intruded by various dykes. The Tertiary sedimentary formations are occurring along the coastal belt and are made up of four beds: Alleppey beds, Vaikom beds (Eocene to Oligocene), Quilon beds (Early Miocene) and Warkali beds (Late 


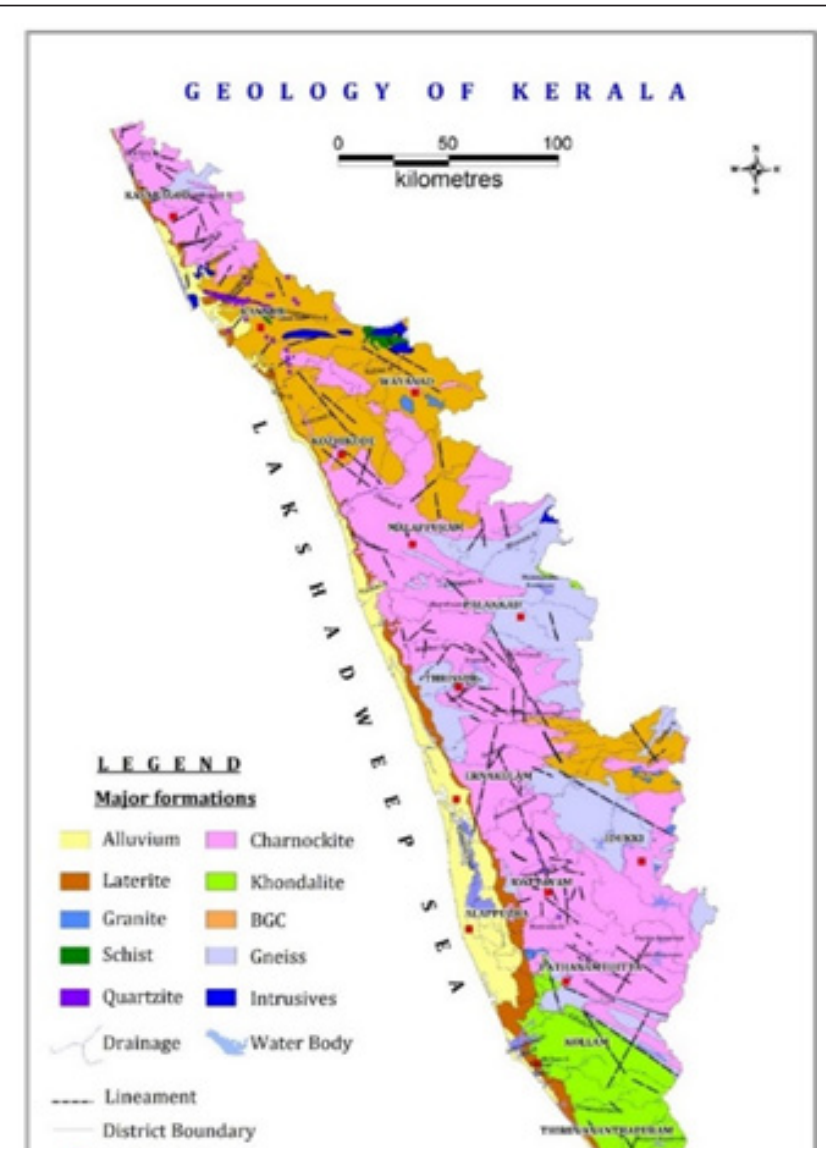

Figure 3: Geological map of Kerala.

Miocene to early Pliocene). The geological map of Kerala State is compiled (Figure 3).

The Kerala State has a limited ground water potential and dugwells function as common extraction structures. The depth of dug-wells with maximum depth of 10 to $15 \mathrm{~m}$ below ground level and having diameter 1-2 in coastal terrain, 2 - 6 midland and high land. Kerala State possesses an appreciable dug-well density (200 wells per $\mathrm{km}^{2}$ in coastal region, 150150 wells per $\mathrm{km}^{2}$ in midland and 70150 wells per $\mathrm{km}^{2}$ in high land).

The problems such as decline in the depth to the water level, drying up of dug-wells, water salinity along the coastal areas are common in Kerala. Even though the depth to the water table (DTW) varies between 0 and 56 meters below ground level, average DTW ranges from 0 to 20 meters below ground. The salient features of various aquifers in Kerala State is compiled (Table 1).

\section{Groundwater Management}

In order to attain sustainability of water resources of the Kerala State various types of artificial recharge scheme to be implemented in Kerala State along with practicing traditional water harvesting measures. The commonly adopted measures in Kerala State for the sustainability include gully plug, gabion structure, percolation tank, check dam, sub-surface dyke, dug, tube and bore well recharge, contour bunding, nalla bund, injection well and so on. People of Kerala State has extensively adopted roof top rain water harvesting structures in their house premises also.

\section{Traditional water harvesting systems}

The various civilizations of the world such as Egyptian, Mesopotamian, Indus valley etc. flourished along the river banks due to the availability of plenty of water resources for the consumption of human beings and animals. The traditional water harvesting structures made for the sustainability of water resources to meet the future demands of water for the flora and fauna when the areas are receiving less rainfall. The nature of traditional rainwater harvesting depends on the rainfall intensity, facilities available and nature of the terrain etc.

\section{Ponds: rainwater harvesting Structure}

Kerala State receives rainfall up to $3000 \mathrm{~mm}$ per year and the good per cent of the water is lost as surface run off and evaporation and the remaining amount recharges the groundwater system. The surface water bodies of Kerala State especially tanks/ ponds also store good amount of surface water and function as a good source for recharge [6]. The surface water is the water stored or flowing on the earth's surface and interacts with the atmospheric and sub-surface water systems [7]. Net surface water available for development from ponds may be taken as $70 \%$ of total volume of water [8]. A very unique feature of the temples in Kerala State is that every temple with a pond or Theerthakkulam (lies on the NE corner of the temple) and Kulappura (outside the temple wall) if there is no river nearby. The pond water is used for the washing of hands and feet, bathing of worshippers before entering the temple premises and Arattu (immersing the idols at special occasions in water) ceremonies. People considers the temple ponds as very sacred and there are different types of temples in Kerala State and these include

\begin{tabular}{|c|c|c|c|c|c|}
\hline Formation & $\begin{array}{l}\text { Depth, } \mathrm{m} \\
\text { below ground } \\
\text { level }\end{array}$ & $\begin{array}{l}\text { Depth to the Wa- } \\
\text { ter table, m below } \\
\text { ground level }\end{array}$ & $\begin{array}{l}\text { Ground water ab- } \\
\text { straction structure }\end{array}$ & $\begin{array}{l}\text { Fracture zone, } \mathrm{m} \\
\text { below ground level }\end{array}$ & Yield \\
\hline $\begin{array}{l}\text { Coastal alluvium \& River- } \\
\text { ine alluvium }\end{array}$ & $<10$ & $<1-6$ & $\begin{array}{l}\text { Filter point well, } \\
\text { shallow dug well }\end{array}$ & - & \\
\hline Laterite & $3-30$ & $3-16$ & dug-wells & - & $0.5-6 \mathrm{~m}^{3} /$ day \\
\hline Fractured crystalline rocks & & $1-25$ & Bore wells & $60 \mathrm{~m}$ and $175 \mathrm{~m}$ & $3,600-1,25,000$ \\
\hline
\end{tabular}

Table 1: salient features of various aquifers in Kerala [5]. 
Citation: Joji VS (2018) Traditional Rainwater Harvesting and Water Conservation Practices of Kerala, South India. J Aquat Res Mar Sci 2018: 84-90. DOI: https://doi.org/10.29199/2639-4618/ARMS.102022.

1. A village temple in every Kerala State villages,

2. A "Desa temple" in every "Desam", within a village,

3. Private family temples, where their family deity is worshipped (Not in every families),

4. Sacred groves, and

5. Transplanted deity temples ("Kudiyiruthukal").

One of the temple ponds is shown below (Figure 4) and all these are ideal and common traditional water harvesting structures seen in Kerala.

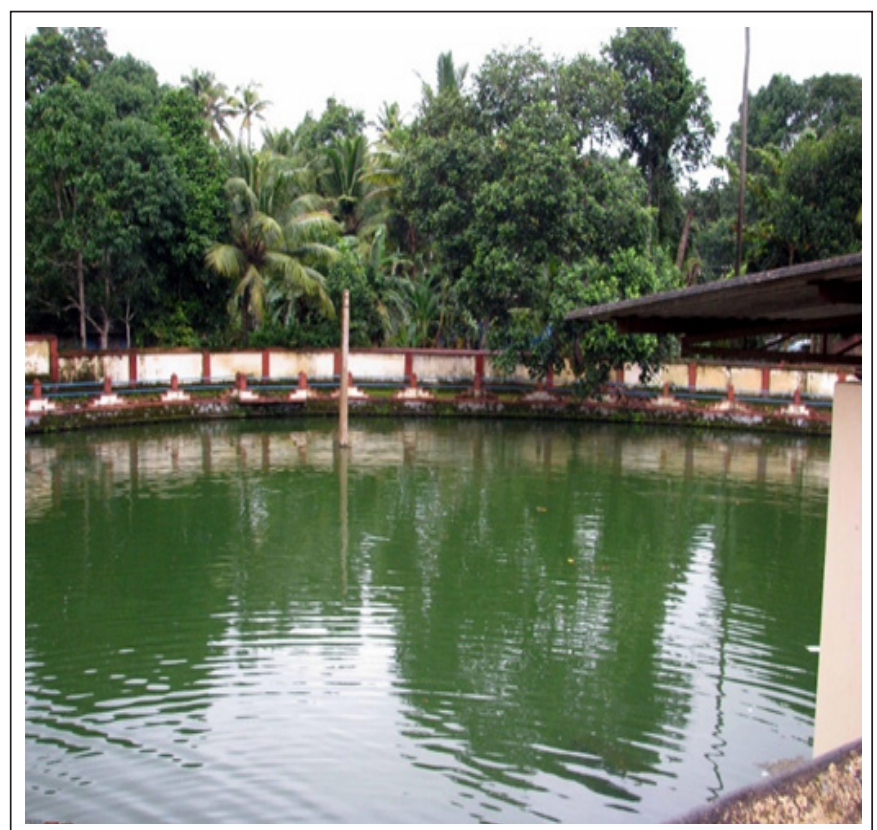

Figure 4: A temple pond, traditional water harvesting structure in Kerala.

Sacred groves (Kavukal) in Kerala State with different types of flora such as mangroves, freshwater swamps, mixed trees, medicinal herbs and so on. The one of the oldest types of nature worship is occurring in Sacred groves and each sacred grove is dedicated to serpent God. Even though worship of serpent common in the temples of India but in Kerala State. The serpent worship is mainly done in sacred groves and salient features of Sacred groves include

- Sacred groves are common in occur in Western Ghats, Central India, northeast India where the indigenous communities live,

- Function as hub for biodiversity conservation,

- $\quad$ Several medicinal plants that rare in the forest are common in sacred groves,

- $\quad$ Endangered, threatened and endemic species are found in sacred groves, and
- The sacredness, religious beliefs and taboos play a significant role in promoting sustainable utilization and conservation of flora and fauna of the sacred groves.

In Palakkad district of Kerala, tanks / ponds are acting as common recharge structures to ground water reservoir and are also acting as traditional water harvesting system generally practiced in the rural areas of the district. In vernacular language tanks / ponds are known as the kulams or eris [6] The ponds / tanks of the Palakkad spread an area of 1-2 acres and very larger ones with a spread area of 3-4 acres. The ponds are in the Palakkad district are mainly used for agricultural purposes.

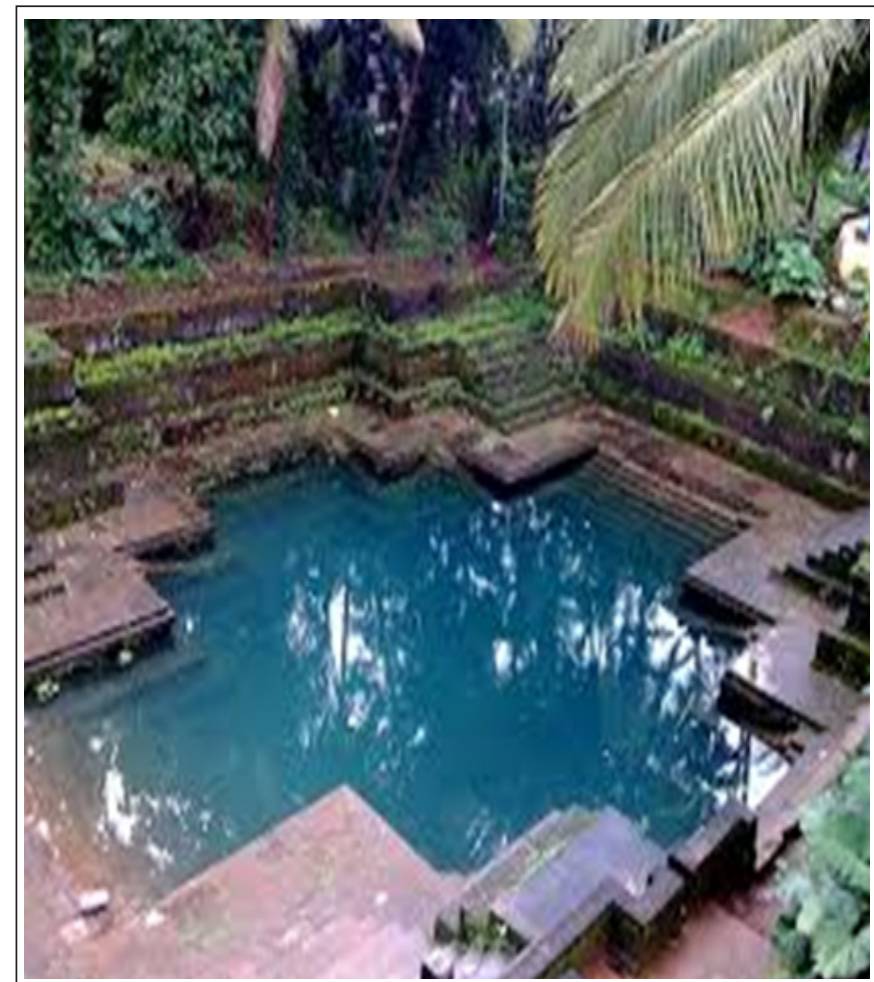

Figure 5: A Kulam (Pond) in Palakkad district, Kerala.

In Palakkad and other districts of Kerala State the most common traditional harvesting structures such as ponds were totally reclaimed or converted for buildup purposes. Now these structures were silted up and water storage capacity drastically reduced.

Usually people of the area divert the rain water to the tanks / ponds before sowing season and they clean the channel before the onset of monsoon. The tanks / ponds function as storage structure (water harvesting) and source of water for agriculture practices especially paddy cultivation. The cluster of ponds, shallow pits and drainage networks enhanced storage and conservation of water in the terrain. Most of the ponds in the area are owned by common men and temple authorities than Govt. departments and these ponds are fitted with energized pump systems and resulted in the change in the water use pattern of the area.

In Kasaragod (northern most district) the terrain is characterized by high discharge in rivers during monsoon and local population utilizing groundwater for domestic and agricultural purposes. 


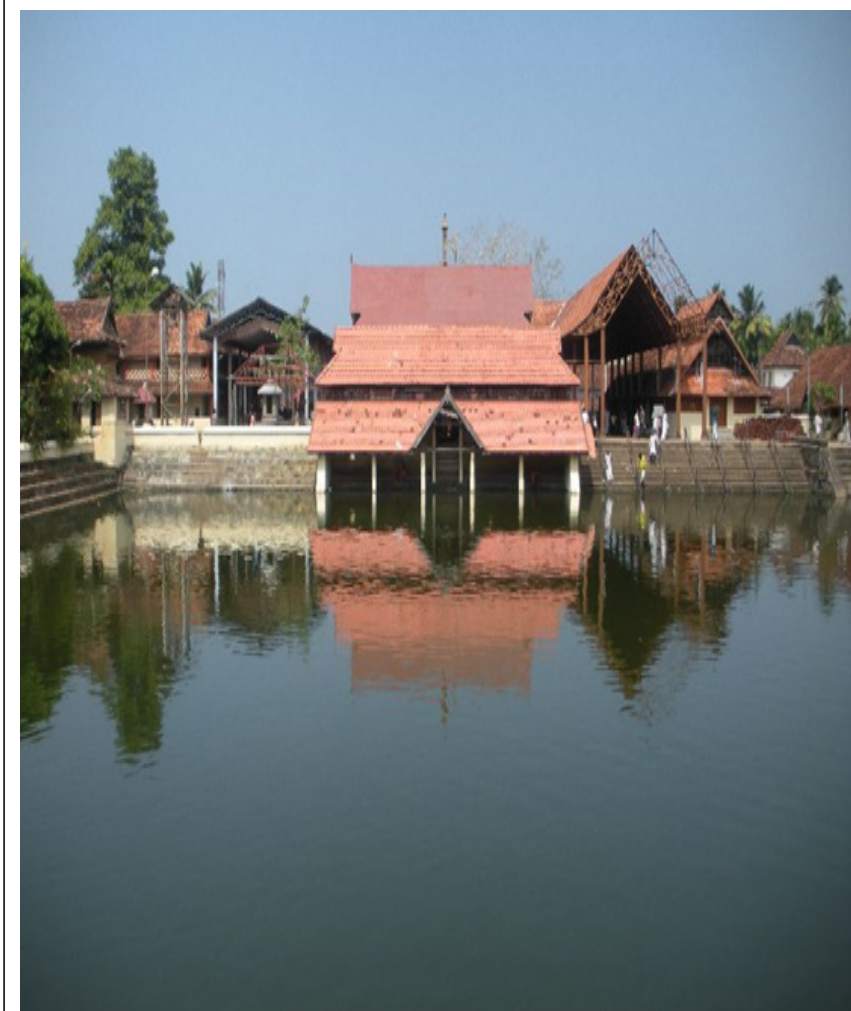

Figure 6: A large Ambalapuzha temple kulam (Pond), Alappuzha District, Kerala.

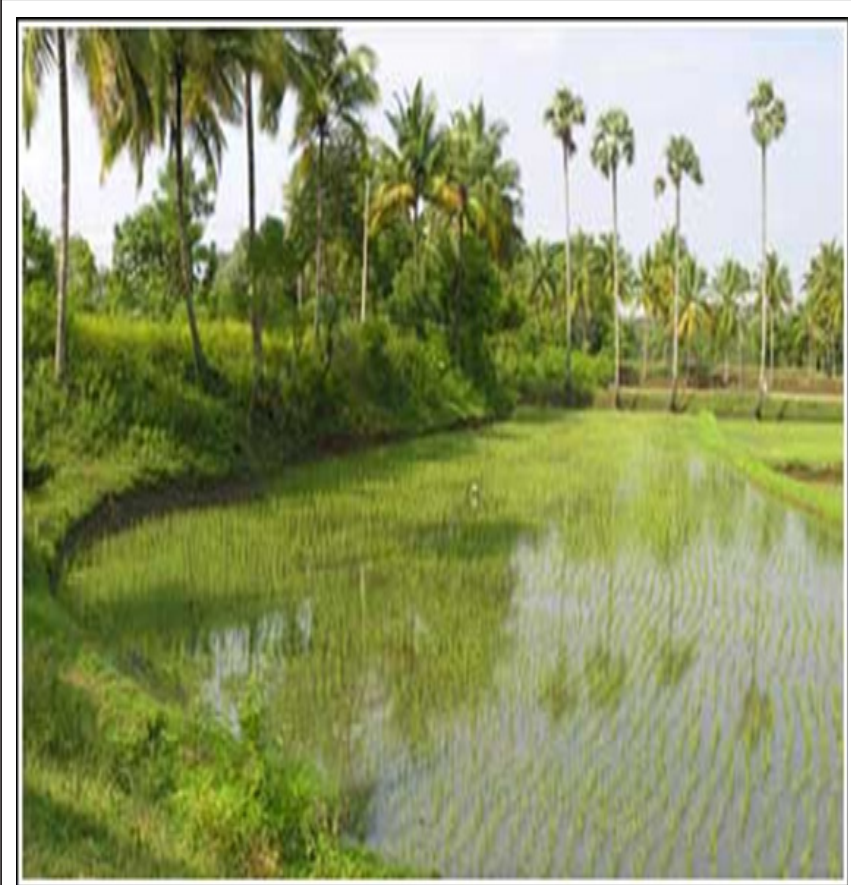

Figure 7: The high bund (varambu) of the pond.

The surangams are the water harvesting structure common in the area. The surangam / thurangam / thorapu is a horizontal well excavated in the sloping laterite formation (Figure 8) and is common in Kasaragod district and areas bordering the South Kanara district of Karnataka and the water coming out of the

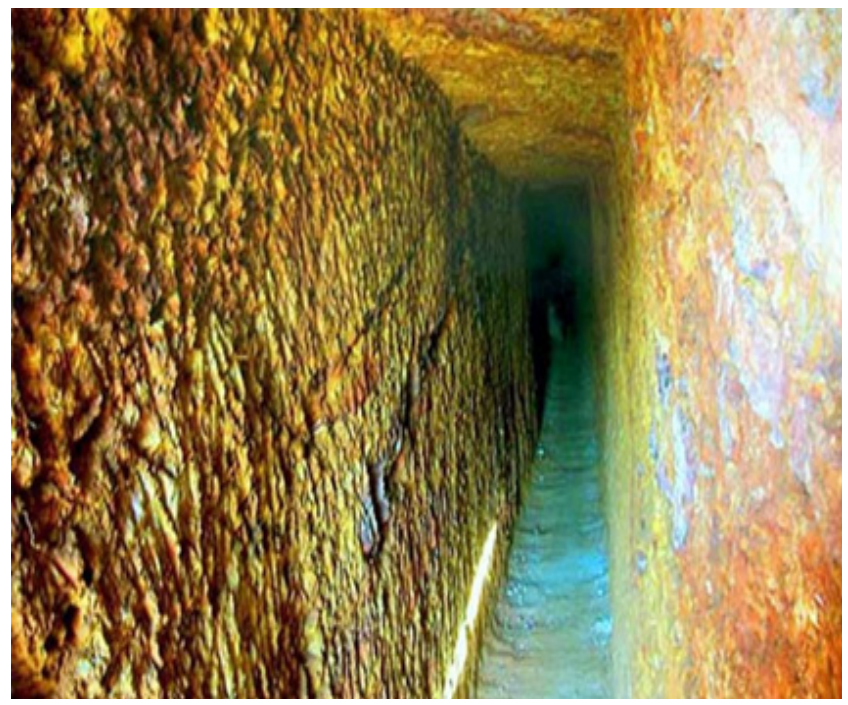

Figure 8: Surangam found in Kasaragod district, Kerala.

tunnel is collected in an open pit outside the structure [9]. The suramgams with $0.45-0.70 \mathrm{~m}$ width, $1.8-2.0 \mathrm{~m}$ height and length of 3-300 $\mathrm{m}$. The surangams are similar to qanats which once existed in Mesopotamia and Babylon and had spread to Egypt, Iran and India.

\section{Role of coconut and arecanut basins in Water Conservation}

The word Kerala is derived from 'Kera' which in malayalam means 'coconut'. The coconut tree is an integral part of the landscape of Kerala State and has an important role in the traditional lifestyle and economy of Kerala. Coconuts in Kerala are more than just a beautiful part of the landscape, the rich and abundant coconut plantations play a major role in the water conservation.

The most common traditional practices adopted for water conservation are

- Mulching coconut/arecanut basins with leaves, coir pith etc.,

- Coconut husk burial in the interspaces of coconut/ arecanut garden,

- Half-moon bund around coconut basin reinforced with pineapple, and

- $\quad$ Trench filled with coconut husk.

Husk burial in the interspaces of coconut palms helps to absorb and retain large quantities of water. Mulching coconut basins with leaves, coir pith etc. prevents evaporative loss of water and helps in retention of soil moisture during summer months.

This low-cost traditional water harvesting system had twin benefits of recharging the ground water as well as increased yield in crops. This method was practiced by farmers in olden days for runoff retention and infiltration which were best suited to the topography and soil conditions of the state but with the advent of 
Citation: Joji VS (2018) Traditional Rainwater Harvesting and Water Conservation Practices of Kerala, South India. J Aquat Res Mar Sci 2018: 84-90. DOI: https://doi.org/10.29199/2639-4618/ARMS.102022.

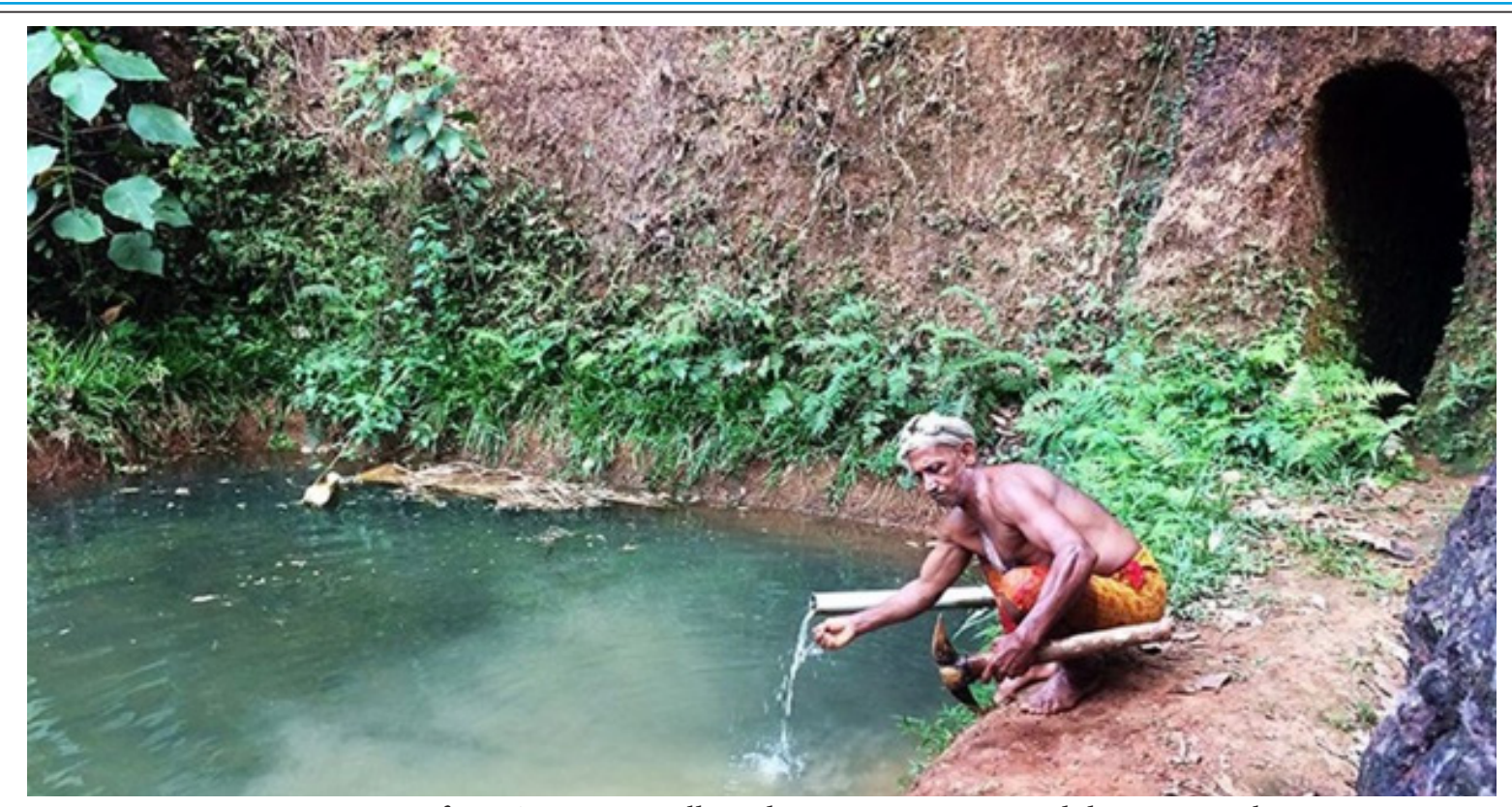

Figure 9: Water from Surangam collected in a sump, Kasaragod district, Kerala.

modern technologies in the form of energized wells, land reclamation for developmental activities, change in cropping pattern etc, this system took a back seat. As a part the Farmers Participatory Action Research Program of the Government of India, farmers were involved for ground water conservation activities and this was availed by the implementing agencies to revive such age-old traditions.

In Kerala State and Karnataka people usually uses saree to catch rain water and thus employing various processes of water harvesting such as catchment, transport and filtration by using sa-

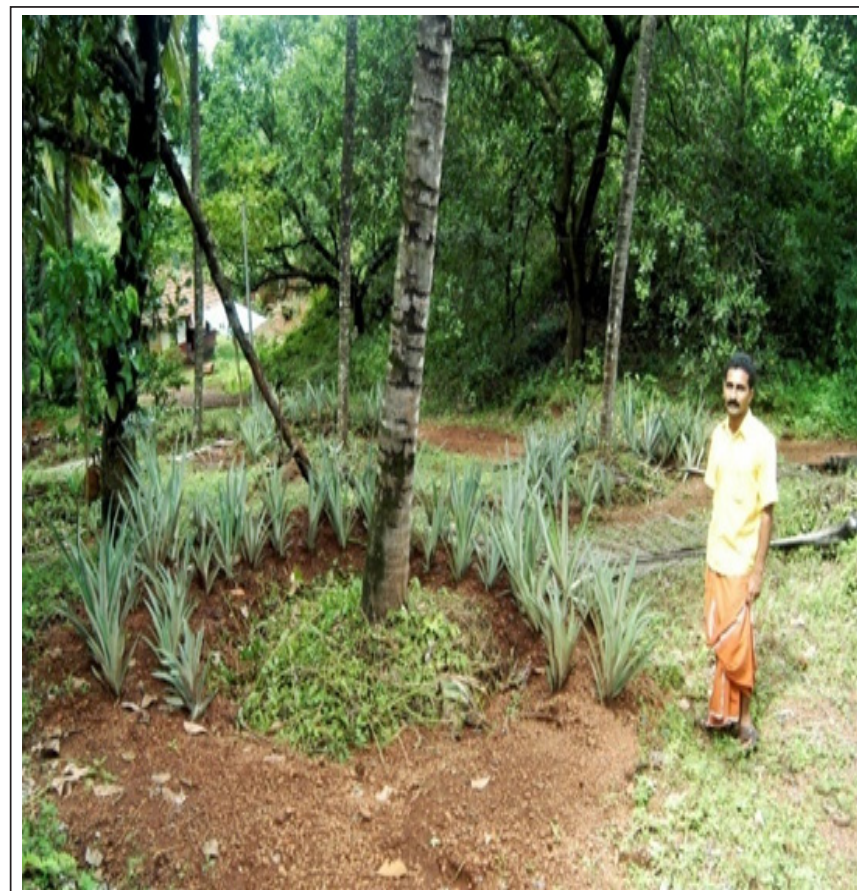

Figure 10: Half-moon bund around the coconut basin reinforced with pine apple.

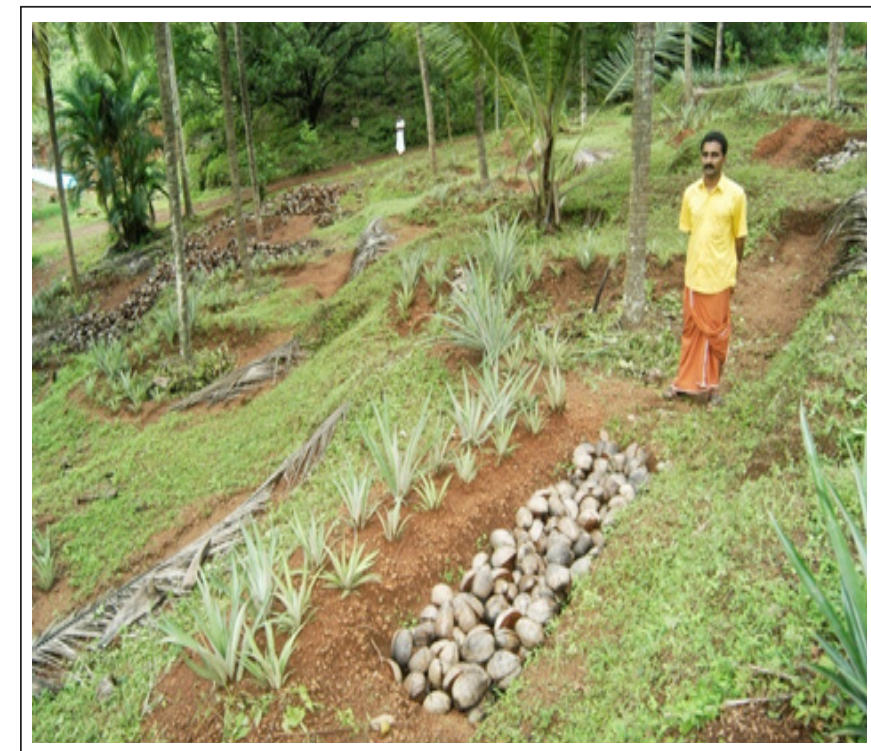

Figure 11: Trench filled with coconut husk.

ree. A makeshift arrangement, the traditional method of RWH is deployed for three months of monsoon in some heavy rainfall areas. In Kerala State it is used in Kuttanad (Alappuzha district). Kuttanad, situated below mean sea level does not have water scarcity, but the water is non-potable. Families boil the water before drinking and also not hesitant to drink rain water.

\section{Acknowledgements}

The author is grateful to the Regional Director, Kerala Region, Central Ground Water Board, Govt. of India, Thiruvananthapuram for all the encouragements given during the course of the work. Thanks, are also due to Deepa K Krishnan, better half the author for the data entry and editing of the manuscript. 
Citation: Joji VS (2018) Traditional Rainwater Harvesting and Water Conservation Practices of Kerala, South India. J Aquat Res Mar Sci 2018 : 84-90. DOI: https://doi.org/10.29199/2639-4618/ARMS.102022.

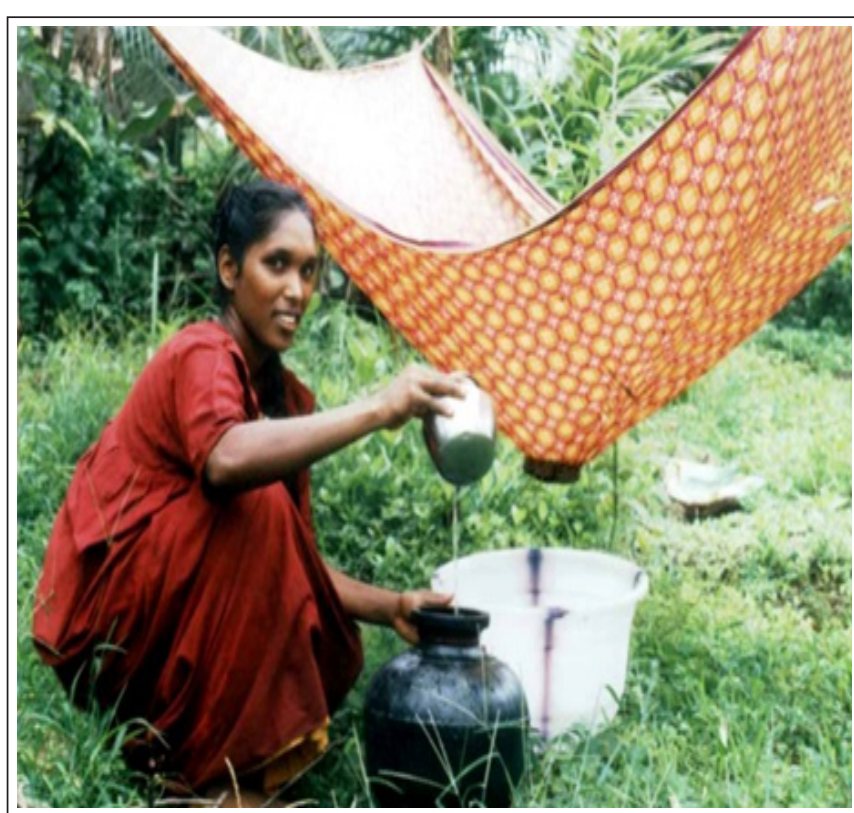

Figure 12: Simplest traditional rainwater harvesting.

\section{References}

1. Gleick PH (1993) Water in crisis. A guide to the world's freshwater resources. Oxford University Press, Oxford.

2. Anon (1994) Manual on Artificial Recharge of Groundwater. Technical Series: Monograph No.3. Central Ground Water Board (CGWB). Ministry of Water Resources, Government of India. pp 215.

3. Census of India (2011): Primary Census Abstract. Figures at a Glance- Kerala.

4. Anon (1995): Land Resources of Kerala State. KSLUB, Thiruvananthapuram. pp.290.

5. Anon (2017) Ground Water Year Book of Kerala. Central Ground Water Board, Kerala Region Thiruvananthapuram, 2016-17.

6. Basak, P, James, E J and Kandasamy, L C (1989): Tanks and ponds of Kerala. Report submitted to Government of Kerala, Unpublished.

7. Chow, V T, Maidment, D R and Mays, L W (1988): Applied Hydrology. Mc Graw-Hill Book Company, New York, pp. 572.

8. Rai, V K (1993): Water resources planning and Development. Deep and Deep Publications, New Delhi, pp. 229.

9. Balooni K, Kalro AH, Kamalamma AG (2010) Sustainability of tunnel wells in a changing agrarian context: A case study from South India. Agric Water Manag 97: 659-665.

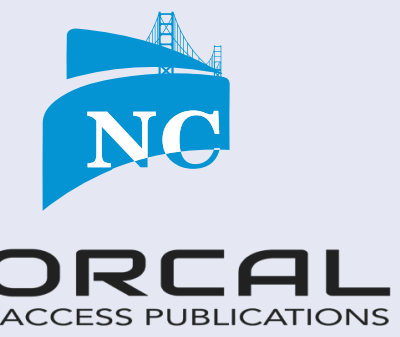

submit your manuscripts at www. norcaloa.com 